\title{
PEMBERIAN FORMULA PAKAN HERBAL TERHADAP PROFIL LIPID PADA AYAM
} PEDAGING

\author{
Oleh \\ Hasan Basri $^{1)}$ \& Rosalina Edy Swandayani ${ }^{2)}$ \\ Universitas Islam Al-Azhar Mataram \\ Email: ${ }^{1}$ hasanbasri7491@gmail.com \& 2 rosalinaedy50@gmail.com
}

\begin{abstract}
This study aims to determine the effect of herbal feeds with different formulas to increase the HSL levels and optimize cholesterol, triglyceride, LDL levels. This study is an experimental study with Completely Randomized Design (CRD). Test animal used in this study were 20 broilers and divided into 4 experimental groups, i.e. P0: control given commercial feed, P1: treatment group given a feed formula, P2: the treatment group given the feed formula, P3: the treatment group given the feed formula. Each group consists of 5 replications. The test animal for each treatment was placed randomly. Data obtained was cholesterol, triglycerides, HDL and LDL levels. The data obtained were analyzed using analysis of variance (ANOVA) and followed by Duncan test with $95 \%$ of significance level if there were significant differences. The data were analyzed with SPSS 25 software for Windows. The results showed that the level of cholesterol, triglycerides, HDL and LDL were not significantly different $(P>0.05)$. The conclusion of this study is that the provision of herbal feed formulas is not significant in reducing cholesterol, triglycerides, LDL, levels and increasing HDL levels, but is able to maintain normal physiological conditions.
\end{abstract}

Keyword: Herbal Feed, Broilers \& Lipid Profile

\section{PENDAHUALUAN}

Peternakan ayam di Indonesia masih menghadapi beberapa tantangan yang harus segera diatasi agar mampu menyediakan daging ayam yang berkualitas tinggi untuk mensuplai kebutuhan nasional. Permasalahan yang dihadapi di antara tingginya penyakit dan rendahnya kualitas ayam. Penyakit pada ayam dapat diketahui dengan pemeriksaan darah, salah satunya dengan pemeriksaan hemoglobin. Menurut Lager \& Jordan, (2012) menyatakan pemeriksaan darah mempunyai nilai lebih dalam proses membantu menegakkan diagnosa atau menjadi bagian dalam program monitoring penyakit metabolik. Pemeriksaan hemoglobin berguna untuk menilai kondisi kesehatan (Togun et al., 2007). Adapun permasalahan lain tuntutan konsumen yang menghendaki daging ayam yang rendah lemak seperti kolesterol, LDL, tetapi tinggi HDL, serta tinggi protein, dan bebas mikrobia patogen serta bebas antibiotika yang terdapat pada pakan. Wuryaningsih (2005) menyatakan bahwa isu keamanan pangan asal http://ejurnal.binawakya.or.id/index.php/MBI ternak yang meresahkan masyarakat antara lain cemaran mikroba patogen dan residu antibiotik dalam daging sebagai efek samping dari pemberian antibiotik dalam pakan yang berfungsi sebagai antibiotik growth promoter (AGP), dalam mengurangi kekhawatiran masyarakat perlu alternatif dalam mengatasinya.

Salah satu alternatif dalam mengatasi permasalahan dengan pemberian pakan herbal. Pakan herbal pada dasarnya merupakan pakan yang komposisinya bersumber dari alam (hewan atau tumbuhan) yang memiliki zat bioaktif. Pakan herbal sebagai feed supplement untuk membunuh mikroba patogen yang mengganggu metabolisme tubuh, sistem pencernaan dan absorpsi nutrisi. Pemberian pakan herbal dapat memperbaiki metabolisme dan meningkatkan daya tahan tubuh yang baik, sehingga dapat meningkatkan produktivitas dan mengurangi penyakit (Donoghue, 2003).

Daun pepaya berfungsi sebagai anthelmintik. Adu, et al., (2009), melaporkan bahwa seluruh bahan dari tanaman pepaya Vol.13 No.12 Juli 2019

\section{Open Journal Systems}


mempunyai potensi untuk anthelmintik. Berbagai zat aktif dalam pepaya yang berefek terhadap mortalitas pada ayam antara lain: saponin, papain, dan karposid (Santas, et al., 2010; Jehan, et al.,2013), yang berguna pada proses pencernaan dan mempermudah kerja usus (Kamaruddin dan Salim, 2002). Sirih berfungsi sebagai antiseptik, antioksidan dan fungisida, sedangkan minyak atsiri yang terkandung mampu melawan beberapa bakteri gram positif dan gram negatif (Moeljanto dan Mulyono, 2003)

Jahe berkhasiat menambah nafsu makan, memperkuat lambung, dan memperbaiki pencernaan. Hal ini didukung oleh Setyanto et al., (2012) dalam hasil penelitiannya ada pengaruh penggunaan tepung jahe terhadap laju pakan. Pendapat Harmono dan Andoko (2005) menyatakan terangsangnya selaput lendir perut besar dan usus oleh minyak atsiri yang dikeluarkan rimpang jahe, sehingga mengakibatkan lambung menjadi kosong dan ayam akan mengkonsumsi ransum. Menurut Winarto (2003), minyak atsiri dan kurkumin berperan meningkatkan kerja organ pencernaan, merangsang getah pankreas yang mengandung enzim amylase, lipase, dan protease untuk meningkatkan bahan pakan.

Serbuk Kunyit mengandung kurkumin 7.97\% (Saraswati et al., 2013a), kurkumin dalam kunyit mempunyai efek antiinflamasi, antioksidan, dan juga sebagai hepatoprotektor (Chattopadhyay et al., 2004; Kohli, et al., 2005; Yarru et al., 2009). Aetin et al. (2017) menyatakan pemberian pakan organik dan serbuk kunyit mampu menurunkan kadar LDL sebesar $37.48\left(10^{-4} \mathrm{x} \mathrm{mg} / \mathrm{m}^{3}\right)$ dari perlakuan kontrol sebesar $91.76\left(10^{-4} \times \mathrm{mg} / \mathrm{m}^{3}\right)$. Putra dkk, (2015) juga menyatakan pemberian suplemen serbuk kunyit sampai dosis $108 \mathrm{mg} /$ ekor/hari sebelum masak kelamin mampu menurunkan kadar kolesterol, LDL dan trigliserida, serta mampu meningkatkan kadar HDL puyuh Jepang.

Berdasarkan hal tersebut, maka dilakukan penelitian tentang pemberian formulasi pakan herbal terhadap profil lipid dan jumlah hemoglobin pada ayam pedaging

Vol.13 No.12 Juli 2019
Penelitian dilaksanakan di Laboratorium Fakultas MIPA Universitas Islam Al-Azhar Mataram, Laboratorium Ternak Unggas Fakultas Peternakan Unram, Laboratorium Hepatika Mataram dan Laboratorium Veteriner Dinas Peternakan dan Kesehatan Hewan Kabupaten Lombok Barat.

Day Old Chick (DOC) ayam pedaging yang diambil di peternakan Baretais Mataram. Aklimasi dilanjutkan di kandang baterai selama 1 minggu. Hari pertama pemberian air gula. Pakan dan minum diberikan secara ad libitum. Vitamin anti stress diberikan pada hari ketiga melalui air minum. Pemberian Vitamin anti-stress bertujuan untuk menambah daya tahan tubuh, mencegah stress pada waktu sebelum dan sesudah vaksinasi. Dilakukan vaksinasi pada umur 3 hari dengan vaksin ND1, vaksin ND2 pada umur 5 minggu. Rute pemberian vaksin melalui tetes mata ayam.

\section{LANDASAN TEORI Pakan Herbal}

Pakan merupakan salah satu faktor yang berpengaruh terhadap kesehatan dan produktivitas hewan. Pakan dengan kualitas dan kuantitas yang cukup sangat dibutuhkan untuk mendukung pertumbuhan dan perkembangan ayam. Alternatif dalam mengatasi permasalahan kesehatan ayam dan produktivitas yang rendah dengan pemberian pakan herbal. Pakan herbal pada dasarnya merupakan pakan yang komposisinya bersumber dari alam (hewan atau tumbuhan) yang memiliki zat bioaktif. Perbaikan metabolisme melalui pemberian pakan herbal secara tidak langsung akan meningkatkan performans ternak melalui zat bioaktif yang dikandungnya (Zainuddin dan Desmayati, 2006).

\section{Profil Lipid}

Profil lipid terdiri dari Kolesterol total, HDL, LDL dan Trigliserida, masing-masing mempunyai fungsi dan kegunaan yang berbeda. Kolesterol adalah zat penting yang terlibat dalam banyak fungsi, seperti memelihara membran sel, memproduksi vitamin D pada permukaan kulit, memproduksi hormon dan membantu http://ejurnal.binawakya.or.id/index.php/MBI 
kemungkinan koneksi sel di otak (Daniels et al., 2009). Kolesterol total darah normal pada ayam normal berkisar antara $125-200 \mathrm{mg} / \mathrm{dl}$ (Mangisah, 2003). Kolesterol darah dapat diartikan sebagai komponen nutrisi dalam darah yang diangkut dalam bentuk lipoprotein. Golongan lipoprotein yang mempunyai peranan utama pada transportasi dan metabolisme dalam darah adalah VLDL, LDL serta HDL (Murray et al., 2009).

HDL merupakan lipoprotein dengan kandungan protein yang paling banyak, fungsi HDL mengumpulkan kelebihan kolesterol dari jaringan tubuh dan mengembalikan ke hati melalui pembuluh darah, serta mengeluarkannya bersama-sama dengan empedu. Kadar HDL darah ayam ras adalah lebih dari $22 \mathrm{mg} / \mathrm{dl}$ (Basmacioglu dan Ergul, 2005). Manoppo et al. (2007) berpendapat bahwa HDL darah ayam yang normal adalah $40-60 \mathrm{mg} / \mathrm{dl}$. LDL merupakan lipoprotein terkecil yang paling banyak mengandung kolesterol dan merupakan pengirim kolesterol utama dalam darah. Sel-sel tubuh memerlukan kolesterol untuk tumbuh dan berkembang yang diperoleh dari distribusi LDL dalam darah. Menurut Manoppo et al. (2007) bahwa kadar LDL ayam normal sebesar 125 $\mathrm{mg} / \mathrm{dl}$, ditambahkan oleh Basmacioglu dan Ergul (2005) bahwa rataan kadar LDL darah ayam ras sebaiknya harus lebih kecil atau lebih rendah dari $130 \mathrm{mg} / \mathrm{dl}$.

\section{METODE PENELITIAN Materi Penelitian}

Penelitian dilaksanakan di Laboratorium Fakultas MIPA Universitas Islam Al-Azhar Mataram, Laboratorium Ternak Unggas Fakultas Peternakan Unram dan Laboratorium Hepatika Mataram.

Day Old Chick (DOC) ayam pedaging yang diambil di peternakan Baretais Mataram. Aklimasi dilanjutkan di kandang baterai selama 1 minggu. Hari pertama pemberian air gula. Pakan dan minum diberikan secara ad libitum. Vitamin anti stress diberikan pada hari ketiga melalui air minum. Pemberian Vitamin anti-stress bertujuan untuk menambah daya tahan tubuh, mencegah http://ejurnal.binawakya.or.id/index.php/MBI stress pada waktu sebelum dan sesudah vaksinasi. Dilakukan vaksinasi pada umur 3 hari dengan vaksin ND1, vaksin ND2 pada umur 5 minggu. Rute pemberian vaksin melalui tetes mata ayam.

\section{Metode Penelitian}

Penelitian ini merupakan jenis penelitian eksperimental dengan Rancangan Acak Lengkap (RAL). Penempatan hewan uji pada setiap perlakuan dilakukan secara random. Sebanyak 20 ekor ayam pedaging yang sudah masuk dalam kualifikasi penelitian, dibagi menjadi 4 kelompok percobaan, kelompok percobaan formula pakan herbal yaitu:

P0: (kontrol) pakan komersial

P1: formula pakan herbal dengan komposisi: jagung $48 \mathrm{~kg}$, bungkil kedelai $15 \mathrm{~kg}$, dedak $20 \mathrm{~kg}$, tepung ikan $10 \mathrm{~kg}$, tepung daun pepaya $3 \mathrm{~kg}$, tepung daun sirih $2 \mathrm{~kg}$, tepung jahe $1 \mathrm{~kg}$ dan serbuk kunyit $1 \mathrm{~kg}$.

P2: formula pakan herbal dengan komposisi: jagung $48 \mathrm{~kg}$, bungkil kedelai $11 \mathrm{~kg}$, dedak $20 \mathrm{~kg}$, tepung ikan $10 \mathrm{~kg}$, tepung daun pepaya $4 \mathrm{~kg}$, tepung daun sirih $3 \mathrm{~kg}$, tepung jahe $2 \mathrm{~kg}$ dan serbuk kunyit $2 \mathrm{~kg}$.

P3: formula pakan herbal dengan komposisi: jagung $45 \mathrm{~kg}$, bungkil kedelai $10 \mathrm{~kg}$, dedak $20 \mathrm{~kg}$, tepung ikan $10 \mathrm{~kg}$, tepung daun pepaya $5 \mathrm{~kg}$, tepung daun sirih $4 \mathrm{~kg}$, tepung jahe $3 \mathrm{~kg}$ dan serbuk kunyit $3 \mathrm{~kg}$. Masing-masing kelompok terdiri dari 5 ulangan. Satu satuan percobaan terdiri dari 1 ekor ayam pedaging. Pemberian perlakuan setiap hari, mulai umur 15 hari sampai umur 5 minggu.

Pengambilan sampel serum dilakukan dengan mengambil darah ayam pedaging dari vena jugularis pada saat proses decapitasi, untuk mendapatkan darah yang maksimal. Ayam pedaging terlebih dahulu dikondisikan dalam keadaan rilek untuk menghindari rigor pada saat decapitasi sehingga tidak terjadi penyumbatan pembuluh darah. Sebanyak $5 \mathrm{ml}$ darah ditampung dalam venojek, kemudian disentrifugasi selama 20 menit pada kecepatan $10.000 \mathrm{rpm}$, sentrifugasi dilakukan untuk memastikan bahwa tidak ada endapan darah yang tercampur dalam serum. Bagian serum yang diambil adalah plasma yang

Vol.13 No.12 Juli 2019

\section{Open Journal Systems}


tidak mengandung fibrinogen atau komponen pembeku darah. Serum yang dihasilkan dimasukkan dalam tabung eppendorf dan disimpan di dalam lemari pendingin sebelum digunakan untuk uji variabel profil kolesterol, trigliserida, HDL dan LDL.

Variabel yang diamati berupa: kolesterol dilakukan dengan metode CHP-PAP (Elwakkad et al., 2012), trigliserida dilakukan dengan metode GPO-PAP (Glycerol Phosphate Oxidase-Para Aminophenazone) (Bekal et al., 2011), LDL dan HDL dilakukan dengan metode CHOD-PAP (Cholesterol Oxidase Phenyl peroxidase Amino Phenozon phenol) (DSI, 2005).

\section{Analisis data}

Data yang diperoleh dianalisis dengan varian (ANOVA), jika ada beda nyata dilanjutkan uji Duncan pada taraf signifikansi 95\%. Analisis dengan perangkat software SPSS 25 for windows

\section{HASIL DAN PEMBAHASAN}

Hasil analisis profil lipid yang meliputi kolesterol, trigliserida, high-density lipoprotein (HDL) dan low-density lipoprotein (LDL) yang telah diberi formula pakan herbal pada ayam pedaging dapat dilihat pada Tabel 1 .

Tabel 1. Hasil analisis kolesterol, trigliserida, HDL dan HDL yang telah diberi formula pakan herbal pada ayam pedaging.

\begin{tabular}{|l|c|c|c|c|}
\hline & \multicolumn{4}{|c|}{ Perlakuan } \\
\hline Variabel & P0 & P1 & P2 & P3 \\
\hline Kolesterol & $131,20 \pm 17,94$ & $105,40 \pm 22,79$ & $134,60 \pm 10,76$ & $128,20 \pm 18,78$ \\
\hline Trigliserida & $54,20 \pm 27,31$ & $45,40 \pm 11,97$ & $27,80 \pm 4,09$ & $43,00 \pm 23,12$ \\
\hline HDL & $98,00 \pm 16,98$ & $83,60 \pm 15,44$ & $102,60 \pm 6,80$ & $98,20 \pm 12,89$ \\
\hline LDL & $26,20 \pm 7,15$ & $20,40 \pm 9,34$ & $28,40 \pm 6,15$ & $25,00 \pm 10,78$ \\
\hline
\end{tabular}

Keterangan: P0: Perlakuan (kontrol yang diberi pakan komersial), P1: perlakuan yang diberi pakan formula (P1), P2: perlakuan yang diberi pakan formula (P2), P3: perlakuan yang diberi pakan formula (P3).

Hasil analisis ragam pemberian formula pakan herbal pada kolesterol pada ayam pedaging menunjukkan hasil tidak berbeda nyata $(\mathrm{P}>0,05)$, walaupun secara statistik tidak berbeda nyata, namun dilihat terdapat variasi antara perlakuan kadar kolesterol tertinggi terdapat pada perlakuan
P2 $(134,60)$, P1 $(131,20)$, P3 $(128,20)$ dan P1 $(105,40) \mathrm{gm} / \mathrm{dl}$. Tidak ada perbedaan nyata kadar kolesterol pada ayam pedaging diduga disebabkan formula kandungan pada bahan pakan herbal tidak maksimal untuk mempengaruhi kadar kolesterol sehingga tidak signifikan dalam penurunan kadar kolesterol serum pada ayam pedaging, namun kadar kolesterol pada ayam pedaging berada pada kisaran normal 131,20 mg/dl, 105,40 mg/dl, $134,60 \mathrm{mg} / \mathrm{dl}$ dan 128,20 mg/dl Tabel 2. Menurut Setyadi et al. (2013) dalam hasil penelitiannya nilai kadar kolesterol ayam broiler pada perlakuan pencahayaan $\mathrm{T} 1, \mathrm{~T} 2$ dan $\mathrm{T} 3$ sebesar $153,33 \mathrm{mg} / \mathrm{dl}, 160,00 \mathrm{mg} / \mathrm{dl}$ dan $142,22 \mathrm{mg} / \mathrm{dl}$. Mangisah, (2003) juga menegaskan jumlah kadar kolesterol darah ayam normal berkisar antara $125-200 \mathrm{mg} / \mathrm{dl}$. Hal tersebut diduga ada penyebab lain yaitu konsumsi pakan yang tidak berbeda nyata. Hasil analisis statistik pada konsumsi pakan menunjukkan hasil tidak berbeda nyata $(\mathrm{P}>0,05)$. Ada dua faktor yang mempengaruhi kadar kolesterol darah yaitu genetik dan faktor makanan. Kamalia dkk. (2014) melaporkan tidak adanya perbedaan keadaan kolesterol karena dapat diketahui $60-70 \%$ kadar kolesterol dihasilkan oleh luar tubuh (makanan). Kolesterol yang digunakan dalam tubuh selain dihasilkan oleh tubuh (60-70\%) juga diperoleh dari luar tubuh (makanan) sehingga pola dan jumlah serta jenis bahan konsumsi akan sangat berpengaruh terhadap kadar kolesterol dalam darah.

Hasil analisis ragam pemberian formula pakan herbal pada trigliserida pada ayam pedaging menunjukkan hasil tidak berbeda nyata $(\mathrm{P}>0,05)$, walaupun secara statistik tidak berbeda nyata namun dilihat terdapat ada penurunan pada setiap perlakuan dibanding perlakuan kontrol, perlakuan kadar trigliserida tertinggi terdapat pada perlakuan P0 $(54,20)$, P1 $(45,40)$, P3 $(43,00)$ dan P2 $(27,80) \quad \mathrm{mg} / \mathrm{dl}$. Penurunan kadar trigliserida tersebut kemungkinan disebabkan kandungan kurkumin yang terdapat pada serbuk kunyit. Putra (2015) menyatakan pemberian serbuk kunyit pada burung puyuh dengan dosis $108 \mathrm{mg} / \mathrm{ekor} / \mathrm{hari}$ dapat menurunkan profil trigliserida serum. Penurunan kadar trigliserida http://ejurnal.binawakya.or.id/index.php/MBI 
serum puyuh Jepang yang diberikan suplemen serbuk kunyit dapat meningkatkan aktivitas lipoprotein lipase (Kohli et al., 2005). Trigliserida bersama protein dan fosfolipid diangkut dalam bentuk lipoprotein berupa kilomikron. Melalui proses eksositosis, kilomikron nascens disekresikan oleh sel epitelium usus ke dalam sistem limfatik, selanjutnya ke dalam darah melalui duktus torasikus. Kilomikron akan terbentuk di dalam darah dan limfe setelah menerima protein dari HDL.

Hasil analisis ragam pemberian formula pakan herbal pada high-density lipoprotein (HDL) dan low-density lipoprotein (LDL) pada ayam pedaging menunjukkan hasil tidak berbeda nyata $(\mathrm{P}>0,05)$, kadar HDL pada perlakuan P0 $(98,00)$, P1 $(83,60)$, P2 $(102,60)$, P3 $(98,20)$ $\mathrm{mg} / \mathrm{dl}$, sedangkan kadar LDL pada perlakuan P0 $(26,20)$, P1 $(20,40)$, P2 $(28,40)$, P3 $(25,00) \mathrm{mg} / \mathrm{dl}$, kadar LDL tersebut masih tergolong normal dibanding dengan hasil penelitian Auza \& Tasse (2015) kadar LDL pada ayam broiler yang diberi kunyit, bawang putih dan mineral zink sebesar 103,75-142,50 mg/dl. Manoppo et al. (2007) juga menyatakan bahwa kadar LDL ayam normal sebesar 95-125 mg/dl. Hal ini dikarenakan LDL dan HDL merupakan dua jenis lipoprotein yang berfungsi mengedarkan kolesterol dalam darah sehingga kosentrasinya di dalam darah sangat dipengaruhi oleh jumlah kolesterol yang disintesis. Hasil penelitian Musa et al. (2006) menunjukkan adanya korelasi positif antara kadar kolesterol dengan LDL dan HDL dalam serum darah. Montgomery et al. (2003) mengemukakan bahwa LDL berperan dalam menyediakan kolesterol dalam jaringan tubuh karena merupakan karier utama untuk kolesterol dari hati ke jaringan tubuh, sehingga kadar LDL dalam darah dipengaruhi oleh konsentrasi kolesterol. Disisi lain, HDL merupakan lipoprotein yang menjaga keseimbangan kolesterol agar tidak menumpuk di dalam sel, keseimbangan dikelola oleh pengangkatan sterol dari membran pada tingkat yang sama dengan jumlah kolesterol yang disintesis menuju hati (Diestchy, 2003).

http://ejurnal.binawakya.or.id/index.php/MBI

\section{PENUTUP}

\section{Kesimpulan}

Berdasarkan hasil penelitian dapat disimpulkan bahwa pemberian formula pakan herbal tidak signifikan dalam menurunkan kadar kolesterol, trigliserida, LDL, dan meningkatkan kadar HDL pada ayam pedaging, namun kondisi fisiologis profil lipid masih dalam kondisi normal.

\section{DAFTAR PUSTAKA}

[1] Adu, O. A., K. A. Akingboye, A. Akinfemi. 2009. Potency of Pawpaw (Carica papaya) Latex as an Anthelmintic in Poultry Production. Botany Res. Int 2(3): 139-142.

[2] Aetin, E. N., T. R. Saraswati, and S. Isdadiyanto. 2017. Blood Lipid Profile of Coturnix coturnix japonica Fed Whith Organic Feed and Supplement Curcuma longa. Biosaintifika 9(3): 560-565.

[3] Auza, F. A dan A. M. Tasse. 2015. Efektivitas Pemberian Serbuk Kunyit, Bawang Putih dan Mineral Zink Terhadap Kadar Kolesterol Darah Pada Broiler. JITRO 2(1): 21-27.

[4] Bekal, M., S. Kumari, R. Vijay and K. C. Pushpalath. 2011. Research Journal of Pharmaceutical, Biological and Chemical Sciences A Study on Lipid Profile and Myeloperoxidase Level in Type II Diabetes mellitus with Respect to Age and Gender. RJPBCS 2(1): 336

[5] Chattopadhyay, I., K. Biswas, U. Bandyopadhyay, and R. K. Banerjee. 2004. Turmeric and Curcumin: Biological Actions and Medical Applications. Current Science 87(1): 4453.

[6] Dietschy, J. M. 2003. How cholesterol metabolism and transport present novel targets for lipid treatment. Adv. Stud. Med. 3(4c): 5319-5323.

[7] Diagnostic System International. 2005. Cholesterol FS. Diagnostic reagent for quantitative in vitro determination of cholesterol in serum or plasma on photometric system. DiaSys

Vol.13 No.12 Juli 2019 
Diagnostic System Gmbh Alte Strasse 9 65558 Holzheim, German

[8] Donoghue, D. J. 2003. Antibiotic residues in poultry tissues and eggs: Human health concerns. Poult. Sci. 82: 618- 621.

[9] Elwakkad, A. S. E., D. B. Alazhary, S. Mohamed, S. R. Elzayat and M. A. Hebishy. 2012.

The

Enhancement Effect of Administration of Caffeine in Combination with Green Tea and its Component on Lipid Profile Elements in Obese Rats. New York Science Journal. 5 (6).

[10] Harmono dan Andoko. 2005. Budi daya dan peluang bisnis jahe. Jakarta: Agromedia Pustaka.

[11]Jehan, B., S. Khon and M. Shafi. 2013. Antimicrobial Potentials of Foods AlliumcepaAgainst

Gram Positif and Negative Bacteria \& Fungi.Pak. J. Bot. 45(S1): 1-6.

[12] Kamalia1., A. Mujenisa dan A. Natsir. 2014. Pengaruh Penambahan Berbagai Level Tepung Daun Katuk (Sauropus androgynus) Terhadap Kadar Kolesterol, Trigliserida, LDL dan HDL Darah Broiler. Buletin Nutrisi dan Makanan Ternak 10(1): 12-1

[13] Kamaruddin, M. dan Salim. 2002. Pengaruh Pemberian Air Perasan Daun Pepaya Pada Ayam : Respon Patofisilogik Hepar. J. Sain Vet. 20(1): $37-43$.

[14] Kohli, K., J, Ali, M. J. Antasari and Z. A. Rahemen. 2005. Natural Antiinflamotory Agent.

Education forum 37(3): 141-147.

[15]Lager, K and E. Jordan. 2012. The Metabolic Profile for the Modern Transition Dairy Cow.

The Mid-South Ruminant Nutrition Conference. Texas Agrilife Extension Service, Texas.

[16] Mangisah, I. 2003. Pemanfaatan Kunyit dan Temulawak Sebagai Upaya Menurunkan Kadar Kolesterol Broiler. Fakultas Peternakan Universitas Diponegoro. Semarang.

[17] Manoppo, M. R. A., R. Sugihartuti, T. S. Adikara dan Y. Dhamayanti. 2007. Pengaruh

Vol.13 No.12 Juli 2019
Pemberian Crude Chrorella terhadap Total Kolesterol Darah Ayam Broiler. Fakultas Kedokteran Hewan. Universitas Airlangga.

[18] Moeljanto, R. D dan Mulyono. 2003. Khasiat dan Manfaat Daun Sirih, Obat Mujarab dari Masa Kemasa. Agromedia Pustaka, Jakarta.

[19] Montgomery, R., R. L. Dryer, T. W. Conway dan A. A. Spector. 1993. Biochemistry : A Case - Oriented Approach. Gadjah Mada University Press, Yogyakarta (Diterjemahkan oleh M. Ismadi).

[20] Musa H. H., G. H. Chen, K. H. Wang, B. C. Li, D. M. Mekki, J. T. Shu and H. P. Ju. 2006. Relation between serum cholesterol level, lipoprotein concentration and carcass characteristics in genetically lean and fat chicken breeds. J. Bio. Sci. 6: 616-620.

[21] Santas, J., M. P. Almajero and R. Carbo. 2010. Antimicobial and Antioxidant Activity of

Crude

Onion (A. Cepa L.). International J of Food Sciences\& Technology 45(2): 403-409.

[22] Saraswati T.R. 2015. Efek Pemberian Serbuk Kunyit Dalam Pakan Terhadap Hepar Puyuh Jepang (Coturnix japonica). Buletin Anatomi dan Fisiologi 94-100.

[23] Saraswati T. R., W. Manalu, D. R. Ekastuti, K dan K. Nastiti. 2013a. Pemberian Suplemen Serbuk Kunyit (Curcuma longa) Terhadap Produktivitas Telur Burung Puyuh. Buku Program dan Abstrak. Seminar Nasional Biologi. Jurusan Biologi Fakultas Sains dan Matematika.Universitas Diponegoro. pp. 233-238.

[24] Setyanto, A., U. Atmomarsono dan R. Muryani. 2012. Pengaruh Penggunaan Tepung Jahe Emprit (Zingiber officinale var Amarum) Dalam Ransum Terhadap Laju Pakan Dan Kecernaan Pakan Ayam Kampung Umur 12 Minggu. Animal Agriculture Journal 1(1): 711-720.

[25] Setyadi, F., Ismadi, V. D. Y. B. dan Mangisah, I. 2013. Kadar Kolesterol, HDL dan LDL Darah Akibat Kombinasi Lama Pencahayaan Dan Pemberian Por. Animal Agriculture Journal 2(1): 68-76.

http://ejurnal.binawakya.or.id/index.php/MBI 
[26] Putra, S. H. J., T. R. Saraswati and S. Isdadiyanto. (2015). Profile Triglycerides Japannes Quail (Coturnix Coturnix japonica) After Giving Turmeric (Curcuma long) Powder. Internasional Journal of Science and Engineering 8(1): 65-68.

[27]Putra, S. H. J. 2018. Profil High Density Lipoprotein (HDL) dan Low Density Lipoprotein (LDL) Serum Puyuh Jepang (Coturnix-coturnix japonica L.) Setelah Pemberian Suplemen Serbuk Kunyit (Curcuma longa L.). Biota 11(1): 26-39.

[28] Togun, V. A., B. S. A. Oseni, J. A. Ogundipe, T. R. Arewa, A. A. Hammed, D. C. Ajonijebu and F. Mustapha. 2007. Effects of Chronic Lead Administration on the Haematological Parameters of Rabbits $-a$ Preliminary Study (p. 341). Proceedings of the 41st Conferences of the Agricultural Society of Nigeria.

[29] Yarru, L. P., R. S. Settivari, N. K. S. Gowda, E. Antoniou, D. R. Ledoux and G. E. Rottinghaus. 2009. Effects of turmeric (Curcuma longa) on the expression of hepatic genes associated with biotransformation, antioxidant, and immune systems in broiler chicks fed aflatoxin. Poultry Science 8(12): 2620-2627.

[30] Waryaningsih, E. 2005. Kebijakan Pemerintah dalam Pengaman Pangan Asal Hewan.

Porseding Lokakarya Nasional Keamanan Pangan Produk Peternakan, Bogor, 14 September 2005. Pusat Penelitian dan Pengembangan Peternakan, Bogor. pp. 9-13.

[31] Winarto, W. P. 2003. Khasiat dan Manfaat Kunyit. Agromedia Pustaka, Jakarta 
HALAMAN INI SENGAJA DIKOSONGKAN 